Pontieri, G. \& Schiano, S. (1958). J. gen. Microbiol. 18, 607-608

\title{
Observations upon the Growing Points in Normal and Filamentous Bacillus megaterium
}

\author{
BY G. PONTIERI AND S. SCHIANO \\ Institute of General Pathology, University of Naples, Italy
}

\begin{abstract}
SUMMARY: Normal bacilli of Bacillus megaterium have large redox-active granules at the poles of the cells, and smaller ones at the periphery, in the region of the crosswalls. In non-septate filaments produced by growth in the presence of urethane the peripheral granules were not present. This is in accordance with the belief that these are the growing-points associated with the development of the cross-walls.
\end{abstract}

The 'growing-points' of bacteria were postulated by Bisset (1951, 1952), who maintained that the growth of the bacterial cell and cell envelopes occurred mainly in the areas at the poles and at the junctions of cell wall and crosswall where basophilic granules were observed. These appear to be the same structures which Mudd (1953) showed to possess redox activity, and which he accordingly equated with mitochondria, although the specificity of these reactions is questionable.

In the present work the occurrence of these granules in normal and in filamentous forms of Bacillus megaterium is examined.

\section{METHODS}

One strain of Bacillus megaterium was used. It was cultivated on nutrient agar plates, and observations were made after 12-14 hr. at $37^{\circ}$. Filamentous forms were produced by addition to the medium of $\mathrm{m} / \mathbf{3 0}$ urethane, according to the technique of Califano \& Pontieri (1951).

Observations were made upon the reduction of 2:3:5-triphenyl-tetrazolium (TTC) and of Nadi reagent.

Observations were made with the electron microscope upon material washed in distilled water, suspended in $\mathrm{N}-\mathrm{NaOH}$ for $1 \mathrm{hr}$. at $60^{\circ}$, and again washed in distilled water, with the object of increasing the electron transparency of the cell envelopes. The preparations were gold-shadowed. Observations were made with a Philips microscope.

\section{RESULTS}

The strain of Bacillus megaterium used was isolated in this laboratory; bacilli grown on nutrient agar without urethane were of normal appearance, divided by cross-walls into several cells per bacillus, and showed large redox-active granules at the poles and smaller ones at the periphery, in the regions of the cross-walls (Pl. 1, figs. 1, 2).

In the presence of $\mathrm{m} / \mathbf{3 0}$ urethane the growth consisted of long filaments, without cross-walls, These showed redox activity only in a series of the large 
granules distributed along the body of the filament in somewhat increased numbers. The smaller peripheral granules were absent (Pl. 1, fig. 3). A similar appearance was shown in the electron micrographs (Pl. 1, fig. 4).

\section{DISCUSSION}

The association of the smaller redox-active granules with the cross-walls of Bacillus megaterium, and their absence from the non-septate filaments produced by growth in the presence of urethane is in accordance with the view that these are growing-points concerned with the development of the cross-walls. If the larger granules, which are retained, and indeed apparently increased in number, in the filaments, are identical with the polar granules of the septate bacilli, then it is reasonable to conclude that these are the main growing-points of the cell, as suggested by Bisset (1951), and in this case, presumably of the protoplasts. The existence of a granular growing-point in naked protoplasts has recently been described by Jeynes (1957).

\section{REFERENCES}

Bisset, K. A. (1951). The development of the surface structure in dividing bacteria. J. gen. Microbiol. 5, 155.

Bisset, K. A. (1952). The interpretation of appearances in the cytological staining of bacteria. Exp. Cell Res. 3, 681.

Califano, L. \& Pontieri, G. (1951). Polymorfismo cellulare batterico da uretano. Boll. Ist. sieroter. Milano, 30, 557.

JeYnes, M. H. (1957). Growth and properties of bacterial protoplasts. Nature, Lond. 180, 867.

Mudd, S. (1953). The mitochondria of bacteria. In Bacterial Cytology. Symp. 6th Congr. int. Microbiol. p. 67.

\section{EXPLANATION OF PLATE}

Fig. 1. Bacillus megaterium, normal bacillus, showing TTC reduction in larger polar granules and smaller peripheral granules in region of cross-walls. Photomicrograph, $\times 4000$.

Fig. 2. B. megaterium, electron micrograph, gold-shadowed; normal bacillus; arrows indicate cross-wall. $\times 10,000$.

Fig. 3. B. megaterium, non-septate filament grown in presence of urethane, showing TTC reduction only in large granules. Photomicrograph, $\times 4,000$.

Fig. 4. B. megaterium, electron micrograph, gold-shadowed; filament grown in presence of urethane, showing absence of cross-walls and series of large granules. 
Journal of General Microbiology, Vol. 18, No. 3
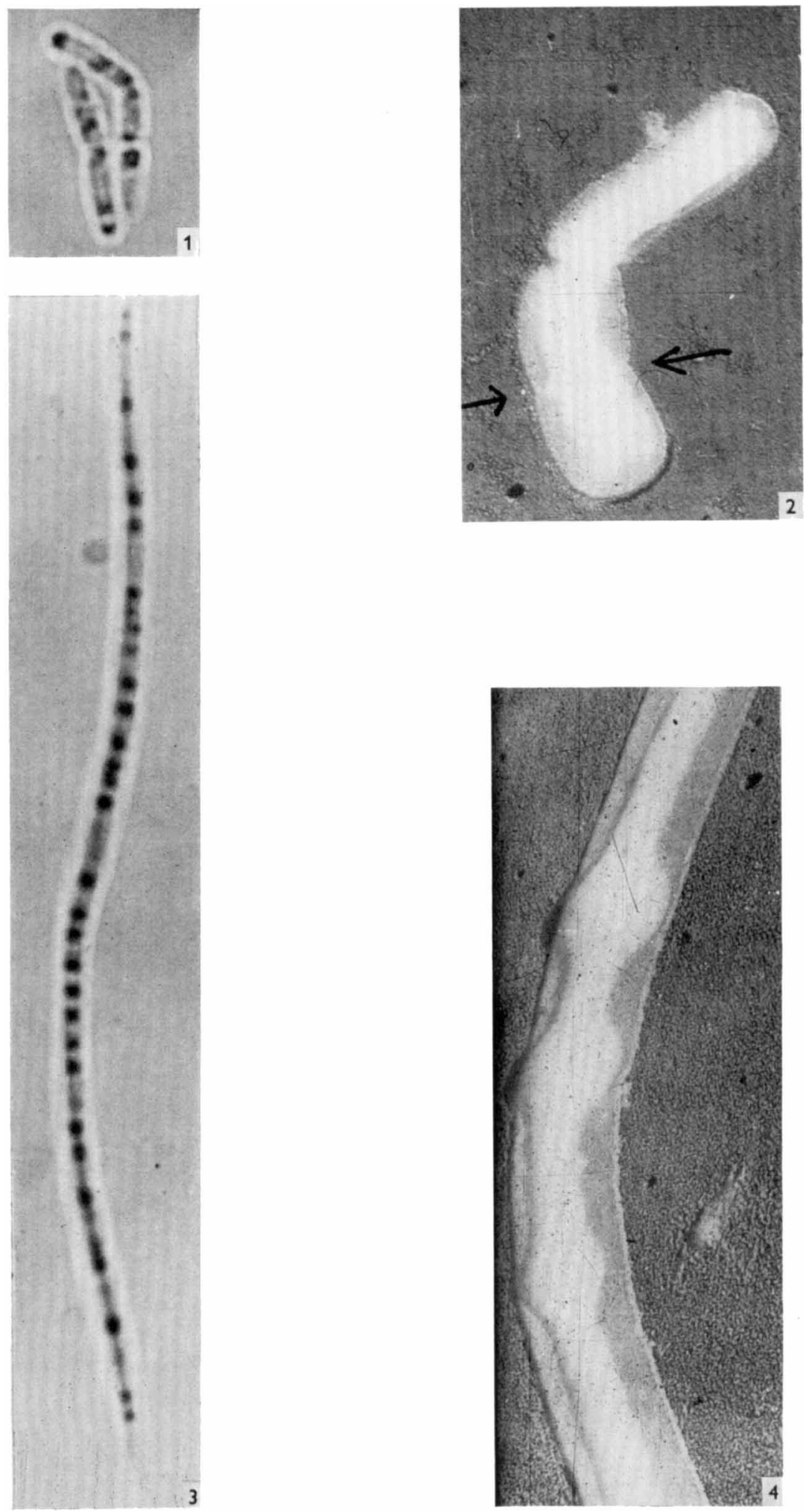

G. Pontieri and S. Schiano-Morphology of Bacillus megaterium. Plate 1

(Facing $p$. 608) 